http://jmscr.igmpublication.org/home/

ISSN (e)-2347-176x ISSN (p) 2455-0450

crossref DOI: https://dx.doi.org/10.18535/jmscr/v7i10.48

Journal Of Medical Science And Clinical Research

IGM Publication

An Official Publication of IGM Publication

\title{
Lichen amyloidosis along with Invasive Squamous cell carcinoma-Report of a case along with a retrospective study and analysis
}

\author{
Authors
}

\section{P.Divya $^{1}$, M.Mounika ${ }^{2}$, P.Viswanathan ${ }^{3}$, B.Krishnaswamy ${ }^{4}$,}

P.K.Kaviarasan ${ }^{5}$, P.V.S.Prasad ${ }^{6}$

${ }^{1,2}$ PostGraduate in Pathology, Department of Pathology, Rajah Muthiah Medical College and Hospital,

Annamalai University, Annamalainagar, Chidambaram

${ }^{3}$ Professor of Pathology, Department of Pathology, Rajah Muthiah Medical College and Hospital,

Annamalai University, Annamalainagar, Chidambaram

${ }^{4}$ HOD \& Professor of Pathology, Department of Pathology, Rajah Muthiah Medical College and Hospital,

Annamalai University, Annamalainagar, Chidambaram

${ }^{5}$ HOD \& Professor of Dermatology, Department of Dermatology, Rajah Muthiah Medical College and

Hospital, Annamalai University, Annamalainagar, Chidambaram

${ }^{6}$ Professor of Dermatology, Department of Dermatology, Rajah Muthiah Medical College and Hospital,

Annamalai University, Annamalainagar, Chidambaram

\begin{abstract}
Squamous cell carcinoma is one of the most common carcinoma involving the skin and squamous epithelium from other sites. They are of varying histological presentation as well as clinical features. Squamous cell carcinoma occurs in a wide range of age group involving both sexes.

Amyloidosis is an extracellular deposition of proteinaceous material which when occurring in skin as a primary lesion is called as lichen amyloidosis. The lichen amyloidosis can have varying forms of clinical presentation. Sometimes amyloidosis is associated with Basal Cell Carcinoma, Bowen's disease and some of cutaneous tumours.

A 4 year analysis of pattern of squamous cell carcinoma as well as Lichen amyloidosis had been analysed and found out that there was one case associated with lichen amyloidosis in a setting of Squamous cell carcinoma.

Keywords: Squamous cell carcinoma, Lichen amyloidosis.
\end{abstract}

\section{Materials and Methods}

Specimens documented as SCC by the Department of Pathology by analysing various samples received from Rajah Muthiah Medical College hospital as well as Neighbouring Institutions were studied in detail regarding, age \&sex incidence, as well as involvement of anatomical sites. In the same way the incidence of Lichen Amyloidosis has also been analysed. The data were retrieved from the archived files.

\section{Observation}

The SCC is one of the common malignancies seen in any of the tertiary care hospitals. The pattern seen in Rajah Muthiah Medical College was analysed regarding the age incidence, sex distribution, involvement of the anatomical site and the histological pattern.

Total surgical biopsies in 4 years-7362

Total number of SCC during the same period-55 in 7362 biopsy specimens 
The various details regarding age, sex, pattern \& the sites where the tumour present are depicted in the chart.

\section{Squamous Cell Carcinoma}

\section{Sex Distribution}

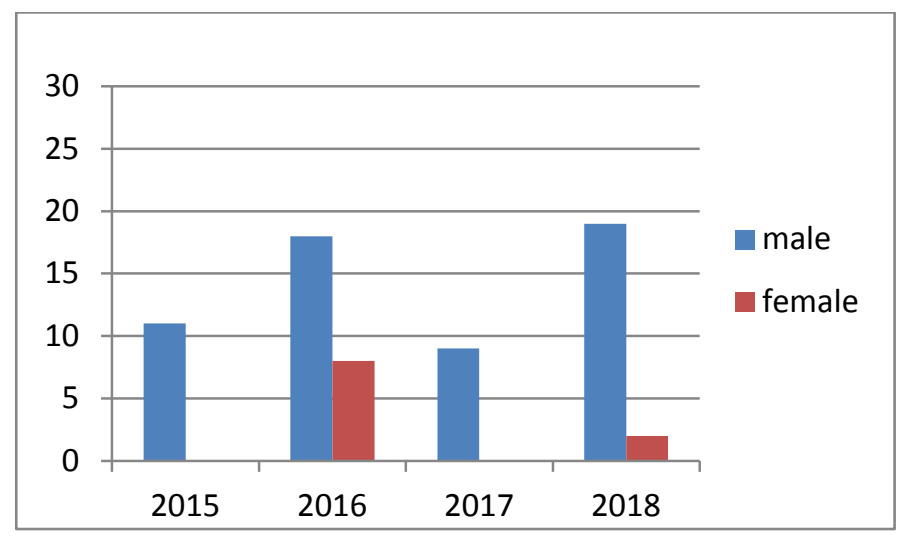

\section{Age-Distribution}

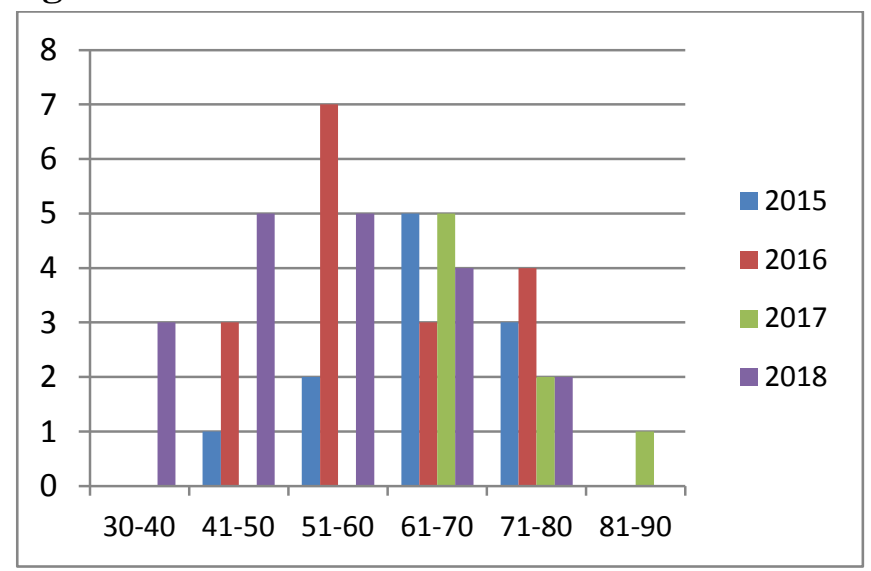

\section{Region Involved}

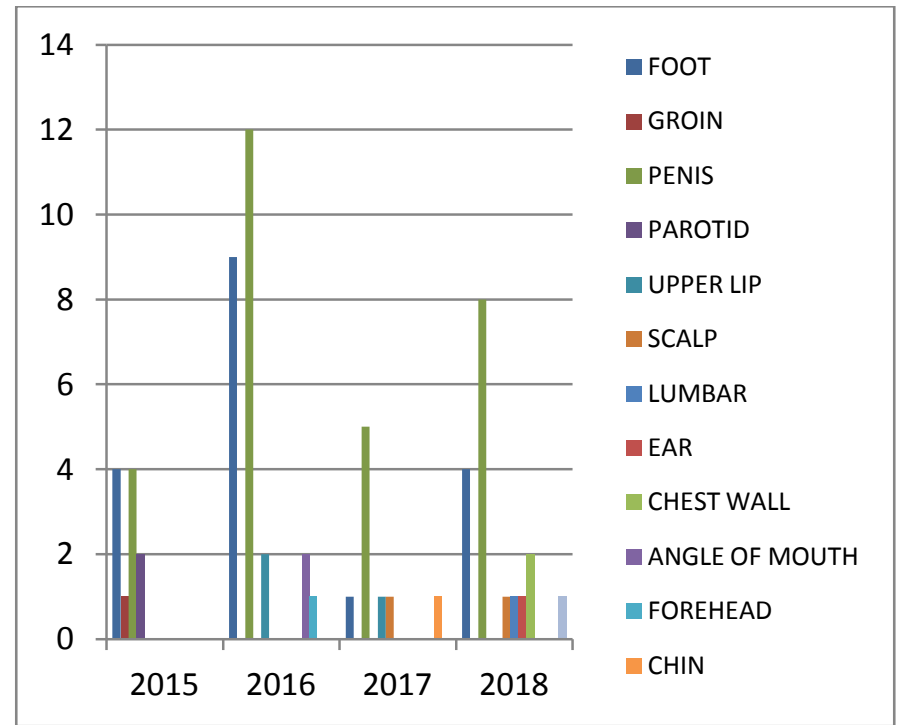

\section{Variants}

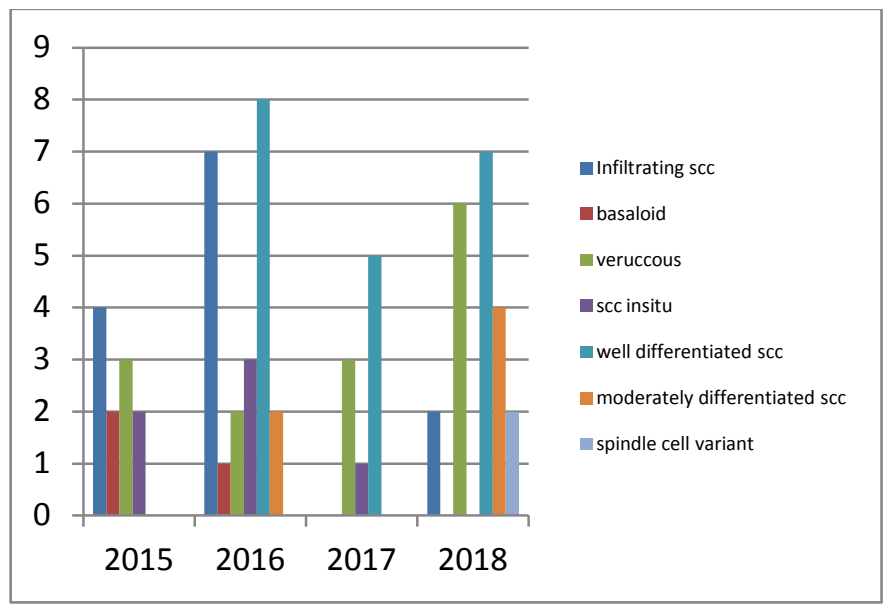

During the same period of time the skin biopsies were also examined in detail.

Total number of skin biopsies-1087

Total number of amyloidosis -13

\section{Lichen Amyloidosis}
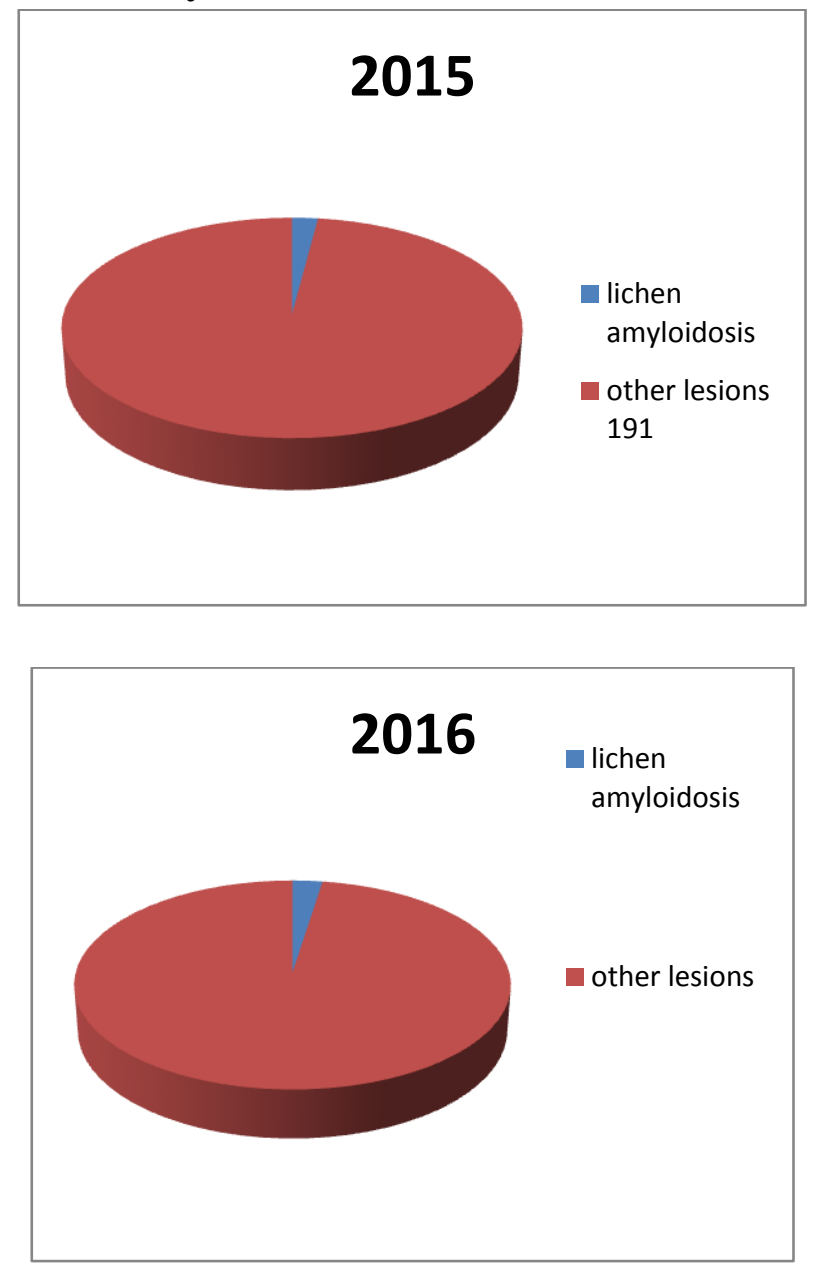

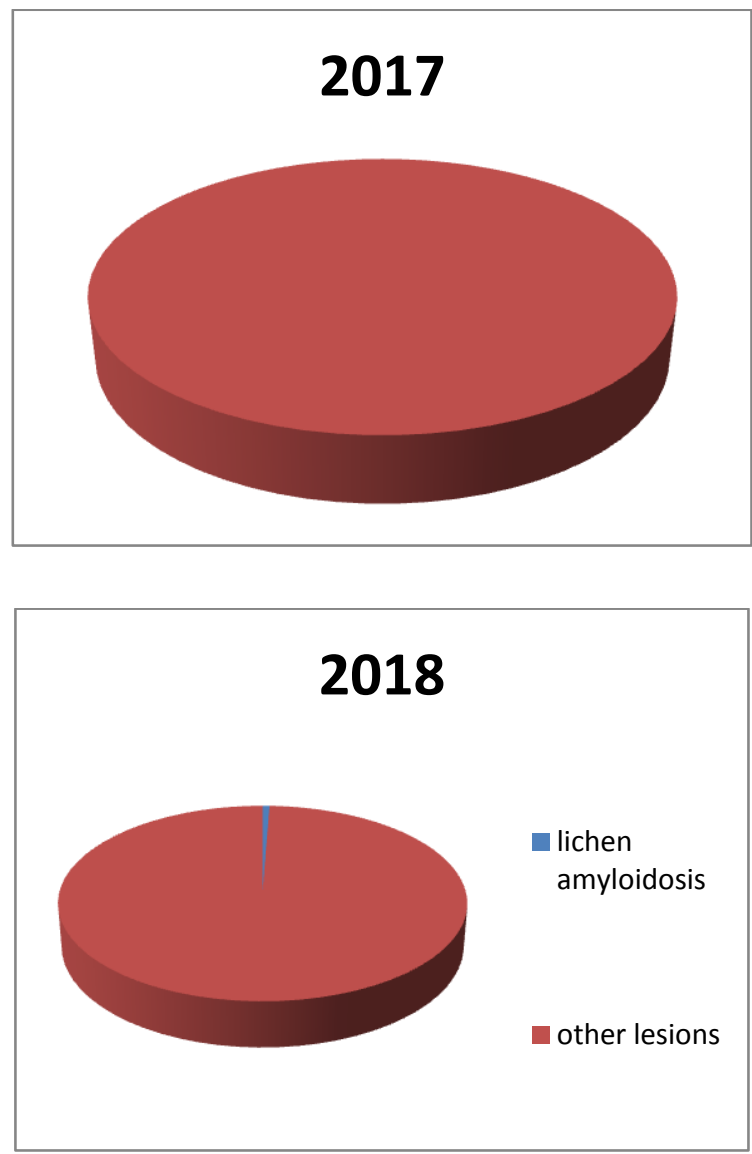

\section{The Present Case Report}

38 year old patient presented with a fungating ulcerating friable growth at the upper $1 / 3^{\text {rd }}$ of lateral aspect of right leg.

She also had ill -defined velvety hyper pigmented follicular papules coalescing to form papules and plaques.

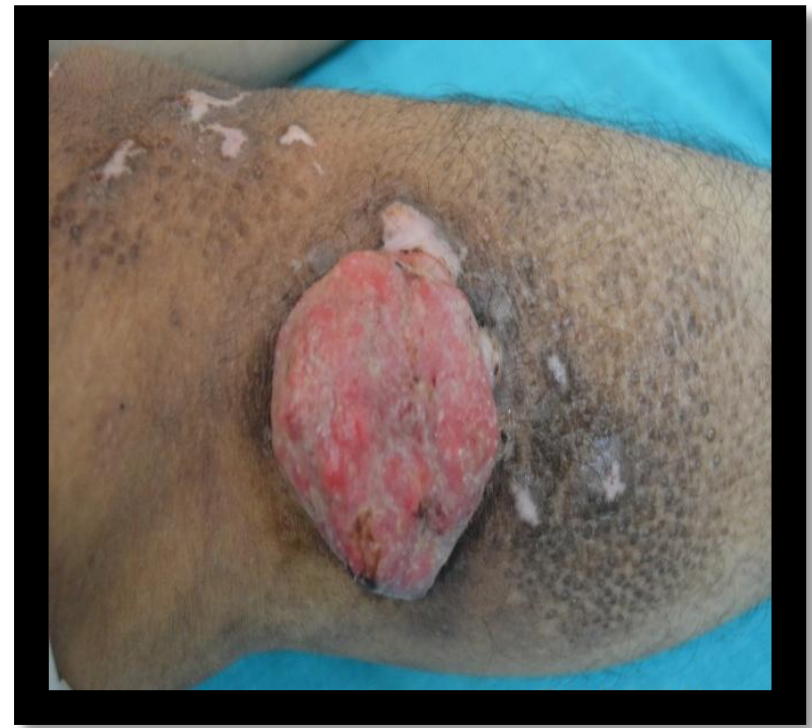

Fig-1 Fungating-fleshy mass with everted margins; the adjacent skin exhibits hyper pigmented plaques of lichen amyloidosis

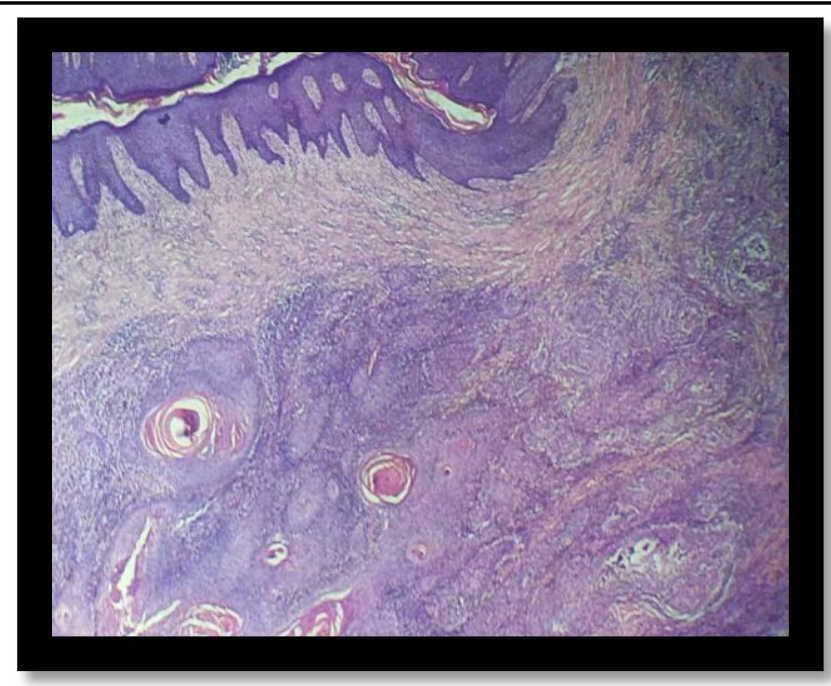

Fig-2 10x -skin with moderately differentiated keratinizing SCC

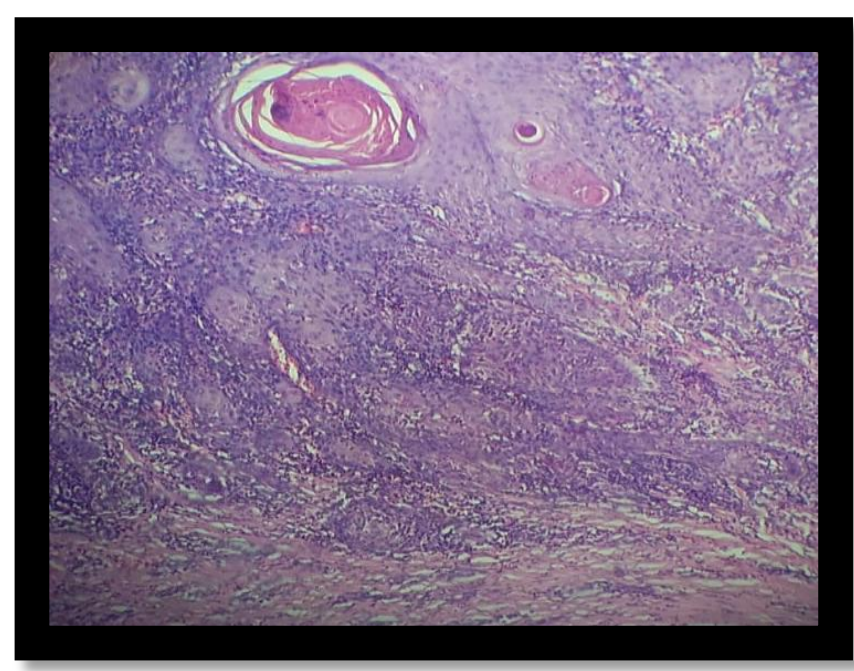

Fig-3 20x-moderately differentiated SCC

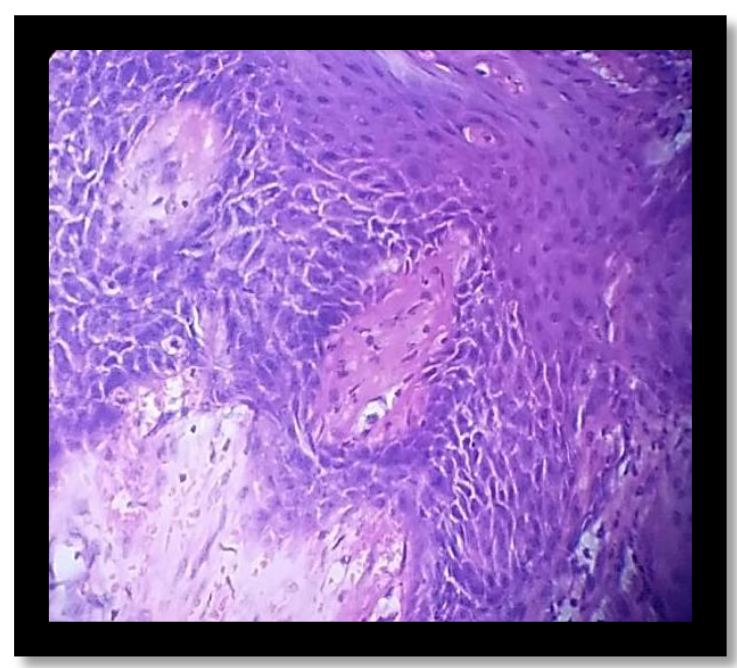




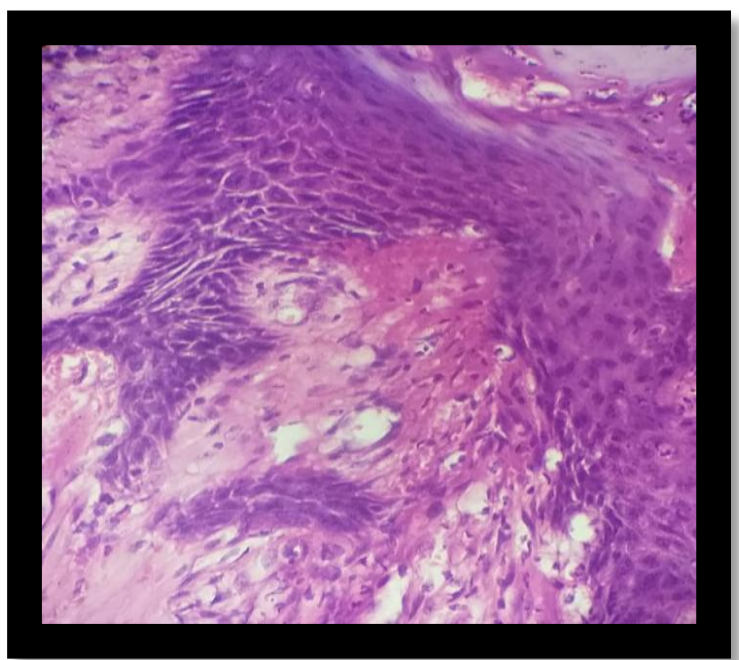

Fig 4 \& 5 - amorphous pink amyloid material in the papillary dermis-depicting amyloid deposits; the adjacent epidermis exhibit pseudoepitheliomatous hyperplasia.
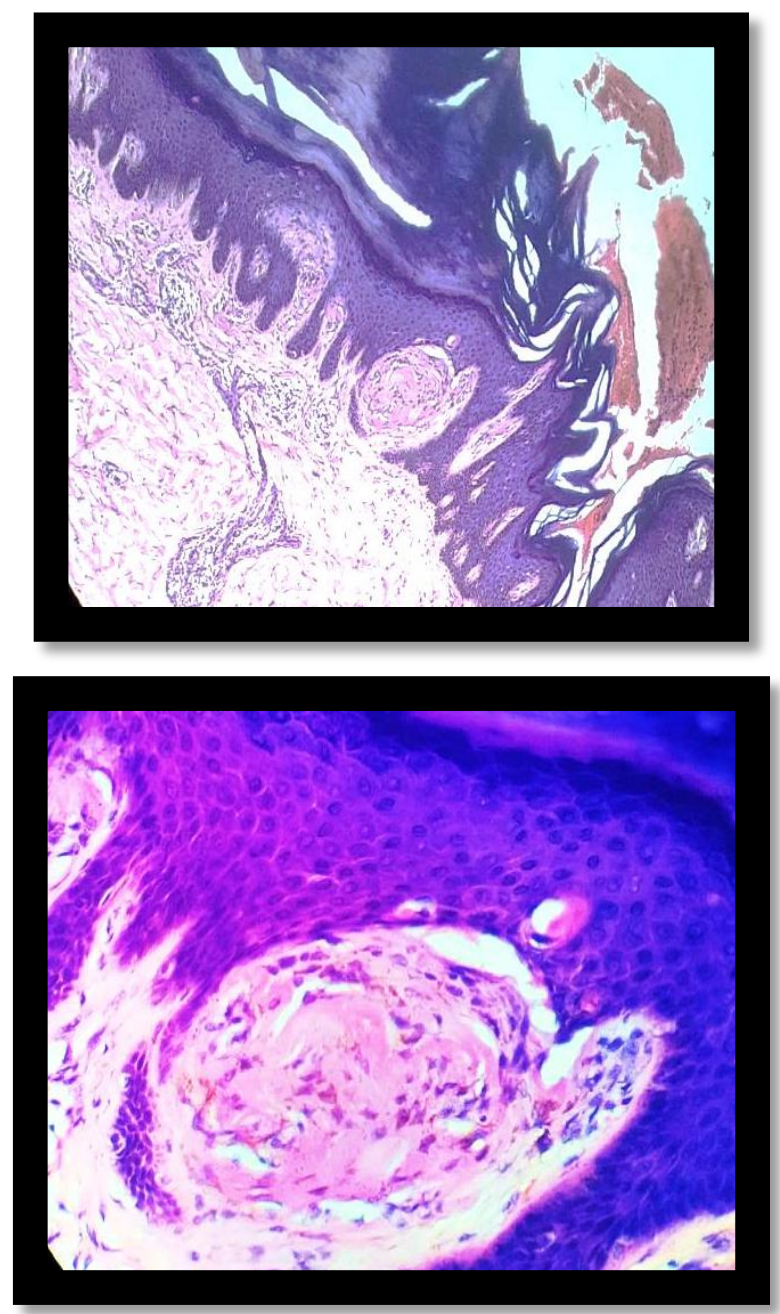

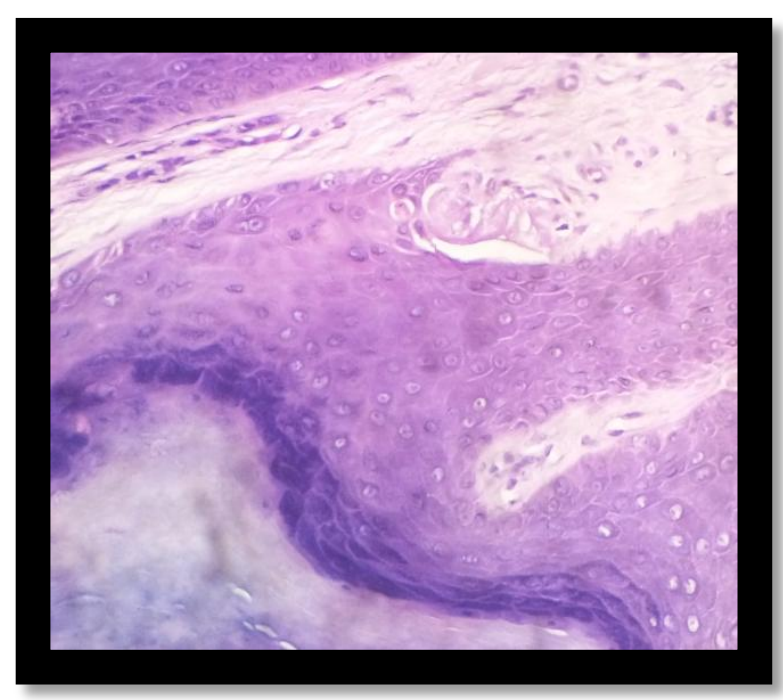

Fig 6,7\& 8 Amorphous pink amyloid material in the papillary dermis depicting amyloid deposits.

\section{Discussion}

The incidence of squamous cell carcinoma were studied during the last 4 years.

Total number of SCC in 2015-11 out of 1955, in 2016-26 out of 1779 , in $2017-9$ out of 1618 and2018-21 out of 2010 biopsies.

Sex Incidence-In all 4 years it showed increased male predominance.

Age Distribution-2015 and 2017-showed incidence in age group of 61-70 years.2016 and 2018 -showed incidence in age group of 51-60 years

Penis was the most common site involved and second most common region is foot.

Squamous cell carcinoma showed male genitalia was most common witha peak incidence in 51-60 years. Most common histological pattern was Well Differentiated keratinizing Squamous Cell Carcinoma, in any site.

Etio-pathogenesis of SCC - The most important cause of cutaneous squamous cell carcinoma is DNA damage induced by exposure to UV light and Ionizing radiation. The Human Papillomavirus -HPV-16 \&18 plays a vital role. Squamous cell carcinoma of the skin can be seen as a complication of the following entities.

1. Xeroderma pigmentosa 
2. Epidermodysplasia verruciformis

3. Cutaneous scars from burns, ionizing irradiation, epidermolysis bullosa, chronic osteomyelitic sinuses, necrobiosis lipoidica, hidradenitis suppurativa etc.

4. Chemical exposure involving arsenic, coal tars \& soot.

5. Immuno compromised individuals

6. PUVA-treated psoriatic patients

7. Icthyosis, epidermal nevus, porokeratosis and congenital lymphedema.

\section{Lichen Amyloidosis}

Various extracellular deposits in papillary dermis in the form of lipid, bone, uricacid, hyaline and amyloid.

Etio -pathogenesis of LA and pathology of LA

Lichen amyloidosis has been reported in association with Alzheimers disease, Lichen Planus and Mycosis fungoides.

\section{Pathogenesis of Amyloidosis}

The major component is composed of polypeptide chains of varying chemical composition, but with a common structural configuration of $\beta$ pleating. The $\mathrm{P}$ component is aminor constituent. Instead of regarding amyloidosis as a disease and attempting to subdivide it, more logical to regard amyloid deposition as occurring in a variety of different diseases the amyloidosis or the $\beta$ fibrilloses.

In generalised amyloidosis, the soluble precursor protein of amyloid present in blood. In reactive systemic amyloidosis there is increased synthesis of SAA in liver, under the influence of interleukin released by macrophages presumably those in aninflammatory exudate. In Immunocyte derived amyloid there is increased blood level of immunoglobulins and light chains.

When the amyloid is derived from transthyretin there is no excess of the parent protein in the blood there is some mutant form of protein present, although why this defect in the protein structure of these proteins predisposes to amyloid deposition is unknown.

The mechanisms involved in the formation of localised amyloid deposits is not understood, but degradation of the parent protein by local mononuclear phagocytes is probably involved.

The possibility remains that the amyloids are normal constituents of the body, and that excessive accumulation occur as a result of defective removal.

\section{Conclusion}

On reviewing the literature it was found out there was no case report of association of SCC with LA. The lady in the case report did not have any known evidences of predisposing factors; in the same way the exact reason for the presentation of amyloidosis was also not clear. The plausible explanation could be an unending supply of free protein from the rapid turnover of the tumour cells, which had triggered the lichen amyloidosis.

\section{Reference}

1. Lohmann, C.M., \& Solomon, A.R.(2001). Clinicopathologic variants of cutaneous squamous cell carcinoma, $8^{\text {th }}$ edition, 27-36.

2. Miller, S.J., \& Moresi, S.J. (2003).Actinic keratosis, basal cell carcinoma and squamous cell carcinoma. In J.L. Bologna, J.L. Jorizzo, \& R.P. Rapini, Dermatology, 1677-1696.

3. Wolff, K, Johnson, R.A., \& Suurmond, D.(2005). Fitzpatrick's coloratlas \& synopsis of clinical dermatology.

4. Non-infectious vesiculobullous \& vesicopustular diseases, Lever's Histopathology of the skin, $10^{\text {th }}$ edition, 427 . 